
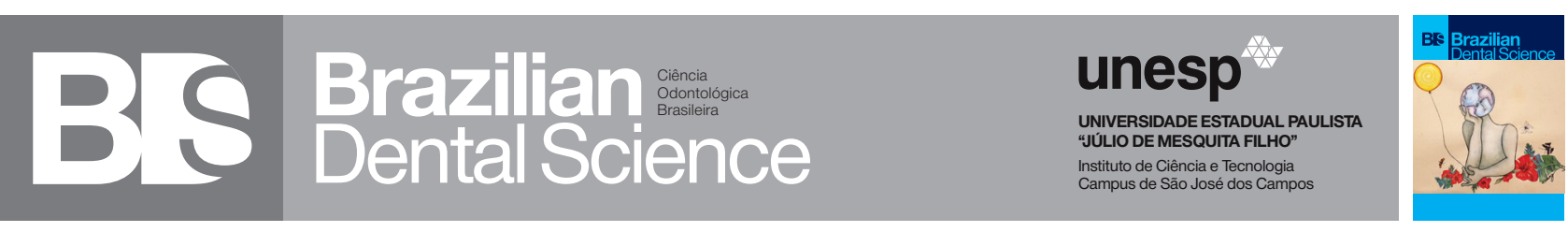

\title{
Effect of topical Insulin administration on bone defect healing in diabetic rats
}

Efeito da administração tópica de insulina na cicatrização de defeitos ósseos em ratos diabéticos

Hany Mahmoud MAHMOUD ${ }^{1}$, Hanyabd-elhamed SHERIFF ${ }^{1}$, Abd-elnasserabd-Elmoala ISMAEL ${ }^{1}$, Alaaabd-alla ZAKI ${ }^{2}$

1 - Oral Biology Department - Faculty of Dental Medicine - Al-Azhar University - Boys - Cairo - Egypt.

2 - Faculty of pharmacy - Al-Azhar University - Boys - Cairo - Egypt.

\section{ABSTRACT}

Objective: insulin has been reported to possess anabolic effect on bone. Topical application of insulin in bone defects in diabetic rats has not been investigated. The objective of this study was to evaluate histologically the effect of topical administration of insulin for the restoration of tibial bone defects in diabetic rats. Materials and Methods: Sixteen adult male albino diabetic rats were grouped into two equal groups, group I (diabetic control) which had not received any graft, group II (experimental) which was diabetic and had received topical insulin loaded on PVP (Polyvinylpyrrolidone). Specimens were harvested on days seven and twenty eight days after surgical procedures, prepared and examined histologically by H\&E (haematoxylin and eosin) stain, there were wide histological differences between the groups of this study along the different intervals of the study.Results:The histological results demonstrated that there was obvious retardation in resolving the inflammatory phase, organization of the blood clot and bone formation in the diabetic control group I than the experimental group II along the different intervals of this study. Moreover, there was great acceleration in granulation tissue formation, organization and bone formation in experimental group II which received the insulin PVP. Discussion: The enhancement in bone healing process was due to the effect of insulin which accelerates the bone regeneration by means of inflammation resolve, angiogenesis, proliferation and successive differentiation of mesenchymal cells. Conclusion: Topical applications of insulin in bone defects enhance new bone formation in diabetic rats.

\section{KEYWORDS}

Insulin; Bone defect; Tibia; Diabetes; Rats.

\section{RESUMO}

Objetivo: Foi relatado que a insulina possui efeito anabólico no osso. A aplicação tópica de insulina em defeitos ósseos em ratos diabéticos não foi investigada. O objetivo deste estudo foi avaliar histologicamente o efeito da administração tópica de insulina na restauração de defeitos ósseos tibiais em ratos diabéticos. Material e Métodos: dezesseis ratos albinos machos adultos diabéticos foram agrupados em dois grupos iguais, grupo I (controle diabético) que não recebeu qualquer enxerto, grupo II (experimental) diabético e recebeu insulina tópica carregada em PVP (polivinilpirrolidona). As amostras foram colhidas nos dias sete e vinte e oito dias após os procedimentos cirúrgicos, preparadas e examinadas histologicamente pela coloração H\&E (hematoxilina e eosina); houve grandes diferenças histológicas entre os grupos deste estudo ao longo dos diferentes intervalos do estudo. Resultados: os resultados histológicos demonstraram que houve retardo óbvio na resolução da fase inflamatória, organização do coágulo sanguíneo e formação óssea no grupo controle diabético I do que no grupo experimental II ao longo dos diferentes intervalos deste estudo. Além disso, houve grande aceleração na formação de tecido de granulação, organização e formação óssea no grupo experimental II o qual recebeu a insulina PVP. Discussão: a melhora do processo de cicatrização óssea deveu-se ao efeito da insulina, que acelera a regeneração óssea por meio da resolução da inflamação, angiogênese, proliferação e sucessiva diferenciação das células mesenquimais. Conclusão: aplicações tópicas de insulina em defeitos ósseos melhoram a formação óssea em ratos diabéticos.

\section{PALAVRAS-CHAVE}

Insulina; Defeito ósseo; Tibia; Diabetes; Ratos. 


\section{INTRODUCTION}

D iabetes mellitus (DM) is a metabolic disorder characterized by high blood glucose level over a prolonged period.DM has led to reduced biomechanical properties of the healing fracture, reduced cellular proliferation and reduced collagen synthesis compared to non-diabetic control animals [1-3].Systemic insulin treatment reverses impaired bone healing in diabetic animals, possibly through enhancement of bone formation and inhibition of bone resorption [4]. However, these studies did not clarify whether this is due to direct and local effect on the fracture repair process or is a secondary effect due to systemic alterations in the metabolic state, such as by reducing hyperglycemia[5].

In vitro Studies have shown that insulin has anabolic effect on bone in diabetic and non diabetic animals, insulin can influence bone growth by directly binding to its receptors presented on osteoblasts [6]. Insulin has been shown to stimulate osteoblast proliferation, collagen synthesis, alkaline phosphatase production and mineralization in bone cell cultures [7]. Insulin promotes osteoclast proliferation by increasing cell cycle and suppressing apoptosis through specific gene regulation [8]. In order to investigate the in vivo direct effect of insulin on bone healing, insulin had been used topically through this study.

\section{MATERIAL AND METHODS}

This study was carried out on sixteen adult male albino rats; their average weight was about $250 \mathrm{gm}$. Diabetes was induced by a single intra-peritoneal injection of $120 \mathrm{mg} / \mathrm{kg}$ monohydrate alloxan dissolved in sterile $0.9 \%$ saline [9].The animals were divided randomly into two main groups as follows: Group (I), control diabetic group consisted of eight rats which had not received any graft. Group (II), experimental group consisted of eight rats which had received the (insulin PVP).

PVP (Polyvinylpyrrolidone) is a water soluble powder was used as a plasma volume expander then used as a binder in many pharmaceutical tablets [10] so it is used in this research as a carrier for the active ingredient which is (insulin).

Surgical procedures; The animals were premedicated by atropine (IM $0.04 \mathrm{mg}$ / $\mathrm{kg}$ ) and anaesthetized intramuscularly with a combination of $2 \%$ xylazine in a dose of $5 \mathrm{mg} /$ $\mathrm{kg}$ (ADWIA, Egypt) and ketamine in a dose of $50 \mathrm{mg} / \mathrm{kg}$ (ROTEXMEDICA, Germany). The overlying skin of the tibia was shaved and disinfected with iodated alcohol. An incision about $1.5 \mathrm{~cm}$ was then made in the medial aspect of the tibia, full thickness flap, the skin, subcutaneous tissue and muscular layer were reflected and a circular $4 \mathrm{~mm}$ diameter defect created.In group I the defect not received any graft while in group II; Equal amount of PVP powder mixed with $1 \mathrm{ml}$ insuman $(1 / 1)$ ratio, after adequate mixing, the paste was divided equally into eight parts and used as grafts. The flap repositioned, the muscular layer was sutured with resorbable \#4.0 catgut and the skin was sutured with interrupted \#4.0 silk sutures.

The procedure management was carried out at house animals of faculty of medicine, cairo university and approved by the local ethical committee.Post operative medications and periodical examination was carried out for the presence of signs of inflammation. Periodical monitoring of blood glucose level was carried out for exclusion of any animal with a blood glucose level less than $250 \mathrm{mg} /$ dl, no animals excluded. Four animals from each group were euthanized after 7 and 28 days post operatively. Area of the bone defect was assessed histologically by H\&E.

\section{RESULTS}

Seven days interval, the group I (diabetic control) demonstrated that the defect was filled with blood clot infiltrated by inflammatory cells, the base of the blood clot showed macrophagic activity. The blood clot 
stabilized by a fibrin network, hemosiderin granules was evidenced at the periphery of the defect. The cortical bone at the margins of the defect showed the normal structure as a lamellar bone, the injured bone marrow at the base of the defect showed inflammatory cell infiltration and sequestrated bone chip surrounded by osteoclasts. (Figure 1)

Twenty eight days interval, the group I (diabetic control) demonstrated well organized granulation tissue at the surface of the defect characterized by tightly packed collagen bundles, osteoblasts, fibroblasts and proliferating blood vessels on the top of woven bone formation. Dispersed, thin and irregular bone trabeculae scattered in the medullary cavity which showed no features of coalescence with each other, insignificant well circumscribed marrow spaces enclosed in the newly formed bone trabeculae, the defect's margin showed union between the newly formed bone and the cortical bone which demarcated by a faintly stained reversal line, the cortical bone at the margins of the defect showed the normal structure as a lamellar bone. (Figure 2)

Seven days interval, the group II (experimental) demonstrated that the graft material occupying the center of the defect, inflammatory cells infiltrating and encircling the graft material. Remnants of the blood clot which contained inflammatory cells mainly macrophages, hemosiderin granules was evidenced at the periphery of the defect. Dispersed collagen fibers forming a meshwork were evidenced at the sides and base of the defect, the cortical bone at the margins of the defect showed the normal structure as a lamellar bone, the injured bone marrow at the base of the defect showed inflammatory cell infiltration and proliferating blood vessels, the defect margins showed active resorption at where howship's lacuna occupied by osteoclasts could be observed. (Figure 3)

Twenty eight days interval,the group II (experimental) showed that the graft material hadn't been completely resorbed wherein small piece of it still observed and showed infiltration by macrophages and undifferentiated mesenchymal stem cells, well organized granulation tissue at the surface of the defect characterized by tightly packed collagen bundles, osteoblasts, undifferentiated mesenchymal stem cells and numerous proliferating blood vessels. The granulation tissue surrounded by new bone trabeculae, primary closure of the defect with a new bone which had thick trabeculae with irregular marrow spaces filled with haemopiotic tissue. The haemopoietic tissue showed mitotic figures of the undifferentiated mesenchymal stem cells, numerous wide lumen blood vessels engorged by RBCs (red blood corpuscles). Numerous and large osteocytes in the newly formed bone disposed in an irregular way and have a wide osteocytic spaces, the newly formed bone was lined by osteoblasts. The central portion of the defect showed maturation of collagen bundles. The newly formed bone was demarcated from the cortical bone by faintly stained reversal line. (Figure 4).

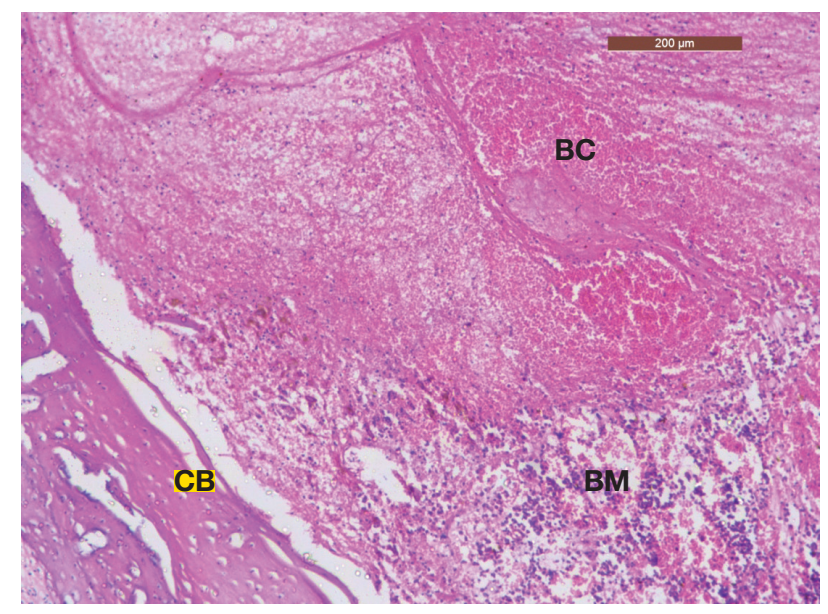

Figure 1 - Histological section of control group at seven days intervals showing blood clot (BC), bone marrow (BM), inflammatory infiltration (thin arrows) and cortical bone (CB) H\&E(Mag.100x). 


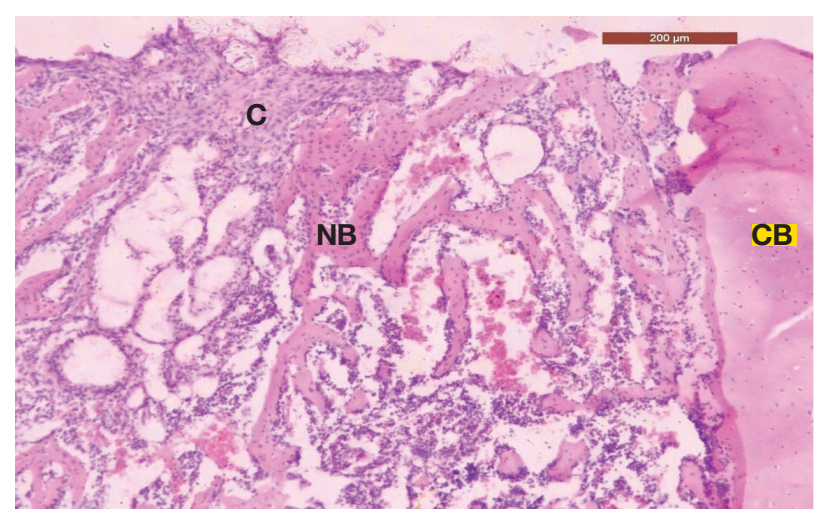

Figure 2 - Histological section of control group at twenty eightdays intervals showing cortical bone (CB), organized granulation tissue with tightly packed collagen bundles (C), sheet of osteoblasts (white arrows), newly formed scattered bone trabeculae (NB).H\&E (Mag.100x).

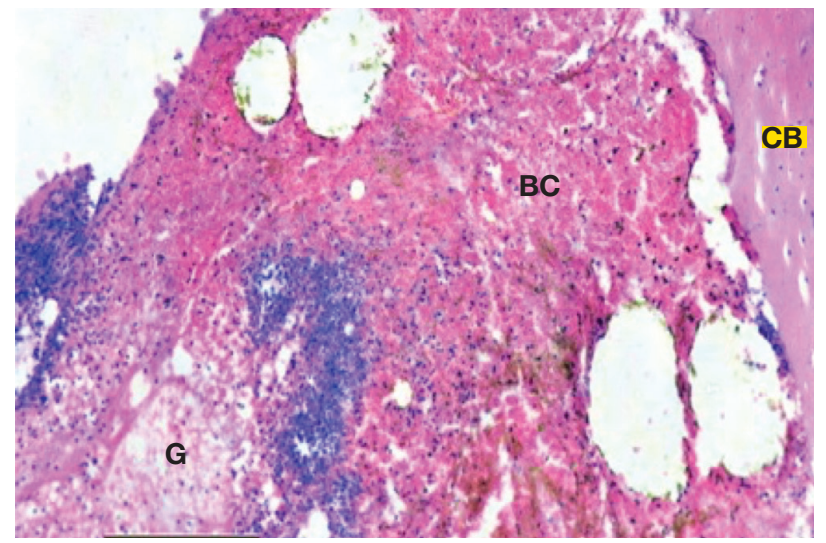

Figure 3 - Histological section of group II (experimental) at seven days intervals showing graft material (G), blood clot $(\mathrm{BC})$, wide lumen blood vessels (arrow head), inflammatory infiltration (thin arrows), hemosiderin granules (brown colour), collagen (C) and cortical bone (CB). H\&E (Mag.100x).

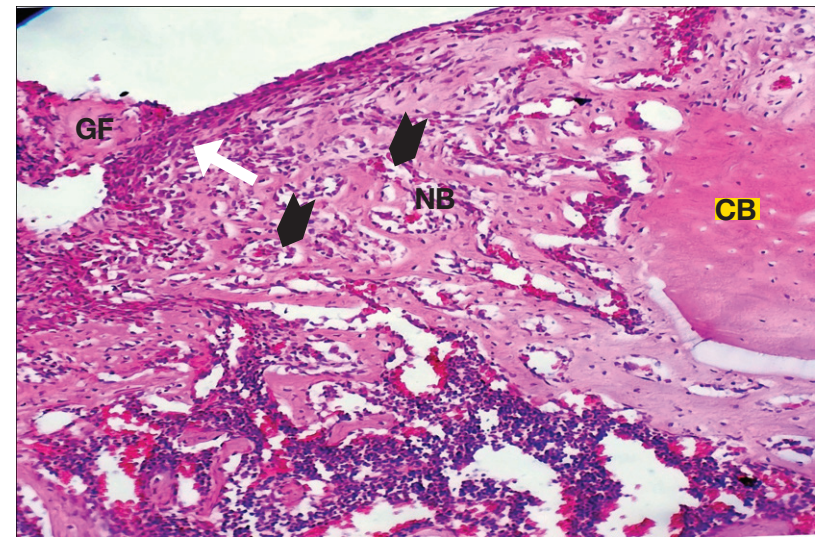

Figure 4 - Histological section of (experimental) group at twenty eight days showing, cortical bone $(\mathrm{CB})$, very thin rim of organized granulation tissue with tightly packed collagen bundles (C), blood vessel (arrow head), sheet of osteoblasts (white arrow), newly formed coalesced bone trabeculae (NB), graft material (GF)H\&E.(Mag. 100x)

\section{DISCUSSION}

The association between DM and impaired osseous healing has been documented in clinical and experimental studies. Several clinical series have noted that the healing time for diabetic patients is approximately twice as long as for non-diabetic patients $[11,12]$. Insulin was known to have anabolic effect on bone[13].

In the present study, the experimental material had been used in a topical way which ensures direct effect on the bone healing cells, PVP used as a carrier to maintain the material and ensure sustained release of it. There were great differences among the groups at the different intervals. The diabetic control group at seven days interval (figure1) showed blood clot without any collagen formation which could be explained by reduction in resolve of inflammation and osteoblasts differentiation.

Orasanu G et al.[14] postulated that advanced glycation end-products (AGEs), defective signal transduction, an imbalance of matrix metalloproteinases (MMPs), increased levels of prothrombotic factors, restricted formation of collateral vessels and increased loss of endothelial cells and pericytes are important aspects of microangiopathy associated with diabetes. Retardation in resolving the inflammatory phase in the control group at seven days interval could be supported and explained by the previous statements.

The insulin PVP group at seven days interval (figure3) showed an evidence of collagen meshwork at the base and sides of the defect which coordinated with Thrailkill $\mathrm{KM}$ et al. [15] who proved that insulin directly increases collagen production by osteoblasts. Also, coordinated with Gabbitas B et al.[4] and Machwate $\mathrm{M}$ et al.[5]both of them stated insulin increased collagen synthesis in the central bone.

In this work, osteoblasts and mesenchymal stem cells showed a prevalence in insulin PVP group than that of the diabetes group which match the statements of Fulzele $\mathrm{K}$ et $\mathrm{al}^{\prime}[16]$ who stated that Insulin has been shown in vitro to stimulate proliferation of osteoblasts, the present findings also 
coordinated with Kream BE et al.[3] who stated that insulin could promote osteoblast proliferation and collagen synthesis.

Histological examination of insulin PVP group at twenty eight days interval revealed continuous advancement in bone healing at where remnants of the graft material still present denoting continuous release of the insulin. Undifferentiated mesenchymal cells surrounding the graft material associated with osteoblasts differentiation and continuous bone formation had been evidenced. The newly formed trabeculae showed features of maturation through coalescence, narrowing of the marrow spaces inbetween them in addition to increase in thickness. The healing of the defect was noted to begin from bone marrow side to the periosteal side (figure4) which correlates with Dedania J.et al. [17]. While the control group revealed dispersed bone trabeculae in the and little mature collagen bundles (figure2)when compared to the experimental group, these findings correlate with other researchers who studied the retardation of bone healing in diabetic models $[13,18]$.

\section{CONCLUSIONS}

1. Topical application of insulin in bone defects induced new bone formation and healing of the defect;

2. Insulin loaded on PVP considered more economic and safer than many other grafts;

3. Insulin loaded on PVP as a biocompatible material can be a clinical option for the reconstruction of large bone defects.

\section{REFERENCES}

1. Moseley KF. Type 2 diabetes and bone fractures. Curr Opin Endocrinol Diabetes Obes. 2012; 19(2):128-35. doi:101097/MED.0b013e328350a6e1.

2. Levy JR, Murray E, Manolagas S, Olefsky JM. Demonstration of insulin receptors and modulation of alkaline phosphatase activity by insulin in rat osteoblastic cells. Endocrinology. 1986 0ct;119(4):1786-92.

3. Kream BE, Smith MD, Canalis E. Characterization of the effect of insulin on collagen synthesis in fetal rat bone. Endocrinology 1985;116(1):296-302.

4. Gabbitas B, Pash J, CanalisE. Regulation of insulin-like growth factor-ll synthesis in bone cell cultures by skeletal growth factors. Endocrinology 1994;135(1):284-9.

5. Machwate M,ZerathE, Holy X. Insulin-like growth factor-l increases trabecular bone formation and osteoblastic cell proliferation in unloaded rats. Endocrinology 1994;134(3):1031-8.

6. Cornish J,Callon KE, Reid IR. Insulin increases histomorphometric indices of bone formation in vivo. Calcif Tissue Int 1996;59(6):492-5.

7. Aronow MA, Gerstenfeld LC, Owen TA, Tassinari MS, Stein GS, Lian JB. Factors that promote progressive development of the osteoblast phenotype in cultured fetal rat calvaria cells. J Cell Physiol. 1990;143(2):213-21.

8. Gerstenfeld LC, Chipman SD, Glowacki J, Lian JB. Expression of differentiated function by mineralizing cultures of chicken osteoblasts. Dev Biol. 1987;122(1):49-60.

9. Federiuk IF,Casey HM, Quinn MJ, Wood MD, Ward WK. Induction of type-1 diabetes mellitus in laboratory rats by use of alloxan: route of administration, pitfalls, and insulin treatment. Comp Med. 2004;54(3):252-7.

10. Bühler V.Polyvinylpyrrolidone excipients for pharmaceuticals: povidone, crospovidone and copovidone. New York: Springer;2005.

11. Loder RT. The influence of diabetes mellitus on the healing of closed fractures. Clin Orthop Relat Res. 1988 Jul,(232):210-16.

12. Cozen L. Does diabetes delay fracture healing? Clin Orthop Relat Res. 1972; 82:134-40.

13. Gandhi A, Beam HA, O'Connor JP,Parsons JR, Lin SS. The effects of local insulin delivery on diabetic fracture healing. Bone 2005;37(4):482-90.

14. Orasanu G, Plutzky J. The pathologic continuum of diabetic vascular disease: J Am Coll Cardiol. 2009;53(5Suppl):S35-42. Doi:10.106/j.jacc.2008.09.055.

15. Thrailkill KM, Lumpkin CK Jr,Bunn RC, Kemp SF,Fowlkes JL. Is insulin an anabolic agent in bone? Dissecting the diabetic bone for clues. Am JPhysiol Endocrinol Metab 2005;289(5):E735-45.

16. Fulzele K, Riddle RC, DiGirolamo DJ, Cao X, Wan C, Chen D, et al, Insulin receptor signaling in osteoblasts regulates postnatal bone acquisition and body composition. Cell2010; 142(2):309-19. doi:10.1016/j.cell.2010.06.002.

17. Dedania J, Borzio R, PagliaD, BreitbartEA, Mitchell A, Vaidya S. Role of local insulin augmentation upon allograft incorporation in a rat femoral defect model. J Orthop Res 2011;29(1):92-9. doi: 10.1002/jor.21205.

18. Funk JR, Hale JE, Carmines D, Gooch HL, Hurwitz SR. Biomechanical evaluation of early fracture healing in normal and diabetic rats. J Orthop Res. 2000:18(1):126-32.

Hany Mahmoud Mahmoud (Corresponding address)

Oral Biology Department - Faculty of Dental Medicine - Al-Azhar University, Boys - Cairo.

Al Mokhaym Al Daem, Egypt.

Date submitted: 2019 0ct 17

E-mail: dr.hanyelagez@gmail.com Accept submission: 2020 Jan 07 